\title{
Coronavirus Disease Outbreak and the Supply Chain of Selected Small and Medium Manufacturing Enterprises in Kenya
}

\author{
Evans T. Mwasiaji (PhD) \\ Department of Business Administration \\ Kenyatta University, Kenya \\ Ambrose O. Jagongo (PhD) \\ Department of Finance \& Accounting \\ Department of Accounting and Finance, School of Business \\ Kenyatta University \\ James O. Ogutu (PhD) \\ Department of Medical Microbiology and Parasitology \\ School of Medicine \\ Kenyatta University
}

\begin{abstract}
The purpose of this study was to investigate the impact of Coronavirus disease outbreak on the supply chain of small and medium manufacturing enterprises in Kenya. The study established that $61.6 \%$ percent of the sampled firms have experienced disruption in their supply chain, with $63.7 \%$ of the sampled enterprises preparing to make adjustments including sending seasonal staff away until the situation improves. $54.5 \%$ are operating below usual capacity, while $98.5 \%$ of the sampled firms projected stock out on inputs. $63.6 \%$ have found it difficult to ship in products due to lack of pre-shipment inspectors who are unavailable due to government movement restrictions in source markets especially in China. The study concluded that Coronavirus disease pandemic has the potential to impact on Kenya's gross domestic product, the government's big four agenda and the sustainability development goals. The study recommends policy initiatives directed at supporting SMEs in Kenya.
\end{abstract}

Keywords: Coronavirus, Supply Chain, Small and Medium Manufacturing Enterprises.

\section{Introduction}

Coronavirus disease of 2019 (COVID-19) caused by severe acute respiratory syndrome coronavirus 2 (SARS-CoV-2), was first reported on December 312019 in Wuhan City, Hubei Province of China (Wu et al., 2020; Malta et al., 2020) and later declared a 'Public Health Emergency of International Concern' by the World Health Organization at the end of January 2020. COVID-19 has now been characterised as a pandemic occasioning one of the worst health crises in a century (WHO, 2020; Nishiura, et. al, 2009). The World Health Organization alerted the world about COVID-19 that was rapidly spreading with over 100,000 cases and 3,800 deaths globally, including over 28,000 cases and 600 fatalities in 100 countries or regions outside China as of March 9, 2020 (WHO, 2020; Kucharski, et. al, 2020; Lee, 2020). Within a few weeks, it became clear that the infection was spreading internationally along major airline routes when hospitals in Italy, Iran, Spain, Brazil, USA, France and Philippines, reported cases with similar signs and symptoms (WHO, 2020; Yu, Zhu \& Zhang, 2020). Globally, consensus is now building that COVID-19 is a zoonotic disease that may have been passed to humans from bats (Lee, 2020). It is now clear that COVID-19 has spread faster and more extensively than the previous respiratory infection outbreaks such as severe acute respiratory syndrome (SARS-CoV), Middle East Respiratory Syndrome (MERS-CoV) and influenza A (WHO, 2020; Kucharski, et. al, 2020; Ji., et. at., 2020). Several studies have reported that transmission occurs mainly from person to person through infected respiratory droplets expelled during coughing or sneezing or after contact with body fluids during certain medical interventions (Zhou, Yang, \& Wang, 2020; Lu, Zhao, \& Li, 2020; Rothe, Schunk \& Sothmann, 2020; Chan, Yuan, \& Kok, 2020; Yu, Zhu, \& Zhang, 2020). Analysis of available epidemiological data by the Chinese Centre for Disease Control and Prevention revealed an overall case fatality rate at about 2.3 to 3.5\% (Fisher \& Heymann, 2020) although it is still too early in the pandemic to conclusively determine this. Fisher \& Heymann (2020) study also established that case fatality rate was higher among elderly (14.8\%) and those with co-morbidities such as cardiovascular, diabetes, chronic respiratory disease, hypertension and cancer (Fisher \& Heymann, 2020). There is still no clear explanation the low morbidity and fatality rates seen among children, or why men are dying more as compared to women. 
Currently there is no proven vaccine nor curative treatment for COVID-19, though antibody tests have been put forth as a reliable method that can confirm infection using acute and convalescent sera (Kucharski, et. al, 2020; Lee, 2020; Casadevall \& Pirofski, 2020). There are, however, vaccine candidates under development and trials for medicines approved for other conditions such as malaria.

Given the changing nature of the ongoing COVID-19 pandemic, governments and regulatory agencies around the world have taken a raft of measures including cessation of movement, quarantine for suspected cases and transportation restrictions so as to slow the speed and reduce the rate of new infections (WHO, 2020). For instance, the United States of America announced an initial thirty days travel restriction especially from European and Asian countries. In Kenya, the government invoked the Public Health Act Cap 242, issued advisories on travel, social and physical distancing, fourteen days self-quarantine for high risk persons, closure of education institutions, cession of religious gatherings and embargos on airlines, hence cutting back on cargo and passenger flights to and from the COVID-19 affected destinations around the world. The international response strategies to COVID-19 pandemic has had implications on the network of organizations that are involved through upstream and downstream linkages, in the different processes and activities that produce value in the form of products and services in the hands of the ultimate end users. The COVID-19 response strategies have therefore impacted on global supply chains with lead times doubling and supply shortages compounded by the lack of air and ocean freight options to move products along the value chains (Berman, 2020). This disruption in global supply chains are likely to impact different organizations in varying proportions and especially the small and medium enterprise sector firms which have inherent weaknesses due to their small sizes and resource capabilities (Mwasiaji, 2020). It is in this era of liberalization of markets that large corporations have largely witnessed tremendous growth in terms of market penetration and geographical expansion (Mwasiaji, 2019).

\section{Problem Statement}

In a globalized and hyper competitive business environment, raw materials and components are sourced worldwide, manufactured off-shore and sold in many different countries with local customization so as to meet the taste and service preference of the end users (Krajewkil, Ritzman \& Malhotra, 2010; Flynn \& Flynn, 2005). Many global companies have dispersed assembly operations to key over-seas locations due to cost advantages, thus have to make use of global logistics channel to supply parts to off-shore assembly plants and after markets (Monezka, et. al., 2009). Many companies where appropriate also use third party organizations to manage distribution and even final finishing (Levi, Kaminksy \& Simchi-Levi, 2008). Supply chain is therefore the set of approaches used by global organizations to efficiently integrate suppliers, manufacturers and warehouses to ensure that products are produced and distributed at the right quantity, transported to the right locations and at the right time in order to minimize system wide costs while satisfying services level requirements (Evans \& Lindsay, 2002; Monezka, et. al., 2009). Unfortunately, the international response strategies to COVID-19 disease outbreak in terms of travel restriction have had implications on global supply chains (Berman, 2020). In Kenya, the countries most affected by the pandemic are important as a source of materials and or markets for products such as electronics, flowers, fresh produce and tea. In the years 2018, Kenya exported products valued at USD 5.4 billion to different parts of the world that are now fast closing their exit and entry points as they try to contain the spread of COVID=19 or keep it at bay (KNBS, 2019). According to Kenya Manufacturers Association (KMA, 2019), a large percentage of manufacturers source their inputs or export to China, USA and European countries. Such manufacturing firms face direct risks of supply chain disruption due to COVID-19 outbreak. For instance, Kenya's small and medium manufacturing enterprise sector is dependent on inputs from China and is likely to be impacted as Chinese factories remains closed due to coronavirus disease outbreak. According to Kenya flower council, the cancellations of flights has left exporters with produce that had been packaged, despite flowers having earned the country USD 1.2 billion in year 2019 (KNBS, 2019). This situation now threatens to aggravate the unemployment crisis as various sectors of the national Economy get affected.

The reported disruption of the network of organizations that are involved along the supply chain is likely to impact organizations in different ways depending on factors such as internal capacity and level of preparedness, though firms in the SME sector are likely to be impacted more, despite their important role in economic development through the generation of employment. With unemployment rapidly reaching new heights arising from existing harsh economic conditions, the COVID-19 outbreak in many parts of the world may worsen the situation for the SME sector development borrowing from lessons learnt during previous disease outbreak (Nishiura, et. al, 2009; Kucharski, et. al, 2020; Lee, 2020). Hence the need for this study to generate data that will be useful in formulating support mechanisms to enable firms in the SME sector regain their footing in a globalised and hyper competitive business environment. 


\section{Methodology}

Small and medium manufacturing enterprises (SMME) with an employment level of between ten (10) and two hundred persons (200) were the unit of analysis for this study. The sampled firms were from a cross section of the value addition sector within Nairobi City County which is the regional business hub, hosting over 80 per cent of the manufacturing firms in Kenya (KAM, 2019). The employment level of between 10 and 200 personnel was arrived at considering the definitions provided in the Micro and Small Enterprise Act of 2012 and that by the European Economic and Social Committee (RoK, 2012; Oslo Manual, 2004). Firms in the value addition sector were chosen because they are not only important in the realization of Kenya's vision 2030, but also because they are critical in industrialization process which is an ingredient towards achievement of Africa agenda 2063 and the global sustainability agenda (Mwasiaji, 2020; United Nations, 2015). Moreover, the manufacturing output is often traded in local, regional and international markets than service output. Value addition firms are also more likely to be in direct competition with foreign enterprises attempting to develop substitute technology using similar processes and targeting the same customers (KNBS, 2019). Senior management staff in the sampled SMMEs were identified as the unit of observation because they were judged to be knowledgeable in the study's subject matter.

A Sampling Frame was prepared as per the list obtained from Nairobi City County Government's licensing department, augmented with the most recent data from the Kenya National Bureau of Statistics (KNBS, 2019). Consequently, 686 firms were identified from the various economic activities in the value addition sector as follows: Food Processing, Wood Workings, Fabricated Metal Products, Non-metallic products and Leather, Textiles and Garments. Out of the 686 firms, only 119 are in the SME bracket and located within the study's geographical setting. The short-listed firms were then categorised into four (4) clusters based on employment level of $10-50,51-100,101-150$ and 151-200. In each of the clusters, the selected firms were further subdivided into five (5) substrata of Food Processing, Wood Workings, Fabricated Metal Products, and Leather, Textiles and Garments. This was done to ensure the sample arrived evenly distributed and thus avoid biased representation of the population. This method was also deemed useful because it was conceived that each stratum would be homogenous internally but heterogeneous with other strata of the population.

Using Krejcie and Morgan's (1970) table of determining sample size, 92 is the number of firms that is required to form a representative sample, out of a population of 119 . The applicable formula is: $s=X^{2} N P(1-P) \div d 2(N-1)+X 2 P$ $(1-P)$, at a confidence level of $95 \%$ and a margin of error of plus or minus $5 \%$, where:

$s=$ required sample size.

$X 2=$ the table value of chi-square for 1 degree of freedom at the desired

confidence level (3.841).

$N=$ the population size.

$P=$ the population proportion (assumed to be .50 since this would provide the maximum sample size).

$d=$ the degree of accuracy expressed as a proportion (.05).

Having determined the required sample size to be 92 SMMEs, five firms out of 119 were used during the pilot study hence unavailable for inclusion in the main study. A sampling fraction was then established using the residue 114 MSMEs. The collected data was analysed using descriptive statistics.

\section{Review of Literature}

\subsection{Theoretical Underpinnings}

Barney (1991) Resource based view (RBV) proposition givesemphasizetoa firm'sproactivechoices. This theory submits that an enterprise can gain a competitive advantage over the long-term if it develops internal proficiencies and capabilities unique to that firm, formulates and produce multifaceted social relationship embedded in a firm's history and culture, and generates implicit organizational knowledge (Odhong et al., 2013). Barney (1991) proposition posits that even though environmentalopportunitiesanddifficultiesareimportant factors for consideration in formulating an organization's strategy,a firm's unique resource suchascapital,equipment,employees,knowledgeandinformation enables it to come up with sustainable competitive advantage especially if these resources have attributes such as rarity, valuable, imitability and non-substitutable. An organization must also be able to exploit those resources or capabilities. Barney (1991) Resource based view places more weight more weight on an organization's human resources that a firm can have (Helfat \& Peteraf, 2003; Holcomb, Holmes \& Conelly, 2009). 
This RBV theory is connected to this study since it emphasizes the importance of availability and effective use of organizational resources, something that puts firms in the SME sector at a disadvantage while competing with larger corporations in a globalized business environment that tends to favor large companies because of the resources at their disposal (Mwasiaji, 2019).

Scylla (1982) regulatory innovation theory is another proposition that is linked to the construct of regulatory framework which is an important variable in the current study. This proposition is relevant to the current study in that it addresses key aspects of an organization's environment including the rules and regulations put in place to control the behaviour of industrial players. Such regulations by governments produce an atmosphere within which an enterprise operates and can therefore influences the survival and growth potentials for small and large businesses. A supportive regulatory framework by governments is important for SME sector firms that seem to be structurally and institutionally marginalized as a result of many factors. A supportive regulatory framework can facilitate SMEs play their role in job creation, poverty reduction and national economic development in the face of disruptions by coronavirus disease pandemic.

\subsection{Supply Chains for SMEs}

It is globally acknowledged that the growth and development of Small and Medium Enterprise sector is core towards realization of sustainable economic development of nations, wealth creation, employment and poverty alleviation (UN, 2015; Baptista, Escaria \& Madruga 2005). The SMEs are also considered training grounds for entrepreneurship and act as channels for mobilizing local savings and ensuring a more equitable distribution of income (Sinha, Akoorie, Ding \& Wu, 2011; Mwasiaji, 2020). With their active industrial initiatives, the SMEs constitute a dynamic and critical part of the private sector whose entrepreneurial viability is essential in inducing responsiveness to fluctuations in the economic conditions of various countries (Beck \& Levin 2005; Mwasiaji, 2020). Despite their importance, it has been shown that Small and Medium Enterprises are very different from large firms. Penrose (2003) uses the analogy that while caterpillars and butterflies are manifestations of the same creature, they cannot be meaningfully compared with each other as the differences are too great. Likewise, Ghobadian and Gallear (1997) in considering the implementation of Total Quality Management (TQM) in business enterprises, conducted a comprehensive review of literature regarding the implications of organizational size. In their report, they concluded that there are significant structural differences between SMEs and large organizations. For instance, they identified 'resource paucity' as the most serious disadvantage faced by SMEs during the implementation of TQM in their enterprises. Here, their definition of the term 'resource' was covering not only financial resources but also knowledge, technical expertise and management time (Yusof \& Aspinwall, 2000; Levratto, Tessier \& Zouikri, 2010; Mwasiaji, 2019).

SMEs have to contend with the constraints that are three-fold in nature. Some are inherent to being small, because small size does in itself imposes costs and innovative penalties in the areas of marketing and technology for lack of economies of scale (Levratto, Tessier \& Zouikri, 2010; Mwasiaji, 2019). Some constraints are an offshoot of distortions in the market and institutions, while others are created by policy interventions. For instance, providers of productive factors such as credit, prefer to work with a few large companies because they are more economically viable (Yeboah, 2015). The argument is that SMEs are more difficult to collect comprehensive information on them, for instance, to facilitate credit rating. They are also said to be more difficult to monitor and the cost of enforcing contracts may be disproportionately large as compared to the size of the transaction (Yeboah, 2015). These kinds of challenges tend to put supplementary strain on SMEs since they have to compete in a globalised business environment that seems to favour larger companies (Sinha, Akoorie, Ding \& Wu, 2011). To be successful, SMEs need to look for competitive advantages within and beyond its own operations, into the value chains of its suppliers and distributors (Nwankwo \& Gbadamosi, 2010). As a result, many SMEs tend to partner with specific upstream and downstream organizations to create a superior value delivery supply chain (Tuan \& Yoshi, 2010; Kotler, 2007). This involves focusing on the value chain that represents the sequence of activities in bringing materials into the business (inbound logistics), and transporting out the final products (outbound logistics) in terms of delivering and supporting its products (Kotler, 2007). The task for the SMEs is to examine its costs and performance in the value chain activities with a view to looking for ways to improve them through collaboration with the vendors around the world (Lunati, 2007). SMEs therefore try to make their supply chains more cost-effective, transparent and responsive to environmental conditions (Mwasiaji, 2019; Nwankwo \& Gbadamosi, 2010). The pathway to the optimal utilisation of the supply chain as a whole is by putting in place a positive relationship between the suppliers and the enterprise. Successful enterprises show that quality supplies, leaner inventories, lower working capital, higher profits and productivity, and better customer service are among the benefits of collaborative behaviour in the enterprise - vendor chain (Sinha, Akoorie, Ding \& Wu, 2011; Tuan \& Yoshi, 2010). 
Moreover, positive relationships established between the enterprise and suppliers enhance synergy and team approach over the individual approach. These relationships ultimately facilitate the many benefits accruing from synergy and alliances against competitors.

In Kenya, the government's big four agenda on food security, affordable housing and universal health care proposes support to the manufacturing sector with a view to raising its share of GDP to 15 percent by 2022 (KNBS, 2019). The manufacturing sector is also a critical pillar towards the realization of Kenya's Vision 2030 due to its strong forward and backward linkages with other sectors in the economy (RoK, 2012). Despite this critical role of the manufacturing sector, its contribution to GDP over the last five years has been on a downward trend according to the Parliamentary Budget Office (Mwasiaji, 2019). For instance, the sector contributed 10.7 percent of GDP in year 2013, though this has progressively declined to 8.4 percent as at 2017 . The manufacturing sector's real value rose slightly by 0.2 percent in 2017 as compared to a growth of 5.6 per cent in 2013. In addition, the manufacturing value addition sector has had very minimal growth stagnating at about USD 5 billion for more than a decade. This shows that Kenya is losing its market share within the East African Community its competitiveness in the international trade (Mwasiaji, 2019; KNBS, 2019). For instance, Kenya had held a dominant position in supplying the region with manufactured goods with Uganda as the largest trade partner, though lately, Kenya's manufactured exports to the region have shrunk considerably. To cement this view, many Manufacturing companies such as Procter and Gamble and Reckitt Benckiser have in the recent past relocated from Kenya to other regions citing high cost of doing business (Mwasiaji, 2019). Given the current internationalized competitive environment where change is a constant, the roadmap to success or failure is driven by (un)responsiveness to environmental dictates and how quickly firms are able to get back on their feet following shocks on the supply chains. Active involvement of suppliers and distributors in the business unit product and / or service development process, is an addition to the arsenal in the war for enterprise strategic repositioning, in terms of gaining efficiencies and streamlining processes and ultimately, improved quality standards (Jara \& Escaith, 2012; Nwankwo \& Gbadamosi, 2010).

\subsection{Coronavirus Epidemiology}

Coronaviruses have become some of the major pathogens in the recent past that primarily targets the human upper and lower respiratory tracts. Previously, epidemics of coronaviruses (CoVs) including severe acute respiratory syndrome Coronavirus (SARS-CoV 1) and Middle East respiratory syndrome Coronavirus (MERS-CoV) occurred in 2003 and 2012 and caused significant public health threats. In the current scenario, groups of patients presenting with pneumonia of unknown aetiology were epidemiologically traced to a seafood and wet animal wholesale market in Wuhan, Hubei Province, China (Kucharski, et. al, 2020; Sasmita, et. al., 2020; Lu, Zhao \& Li, 2020).

Nearly three months after the first official reports, the pandemic has spread to virtually all the continents infecting and killing more than 370,000 and 16,000 people respectively. The available published data can now be used to detail the chronology of epidemiological events in its spread. Following the first official notification given on the last day of 2019, about 41 admitted patients had been confirmed to be suffering from COVID-19 infection in Wuhan, Hubei Province, China by January 2, 2020 and less than half of them also had co-morbidities such as cardiovascular disease, hypertension and diabetes. Most of these patients were presumed to be nosocomial infection cases spreading due to many patients coming into contact throughout the hospital by yet unknown mechanisms (Kucharski, et. al, 2020; Sasmita, et. al., 2020Ji.,et. at., 2020). By the end of the month, the virus had rapidly spread throughout China during the Chinese New Year perhaps aided by the heavy and extensive intra and inter-province travel among Chinese (Bogoch, et. al, 2020; Ji., et. at., 2020). Notably, 106 cases had also been confirmed abroad in 19 countries, from neighboring countries such as Japan and Vietnam to more distant countries such as Finland, Canada and Australia (Kucharski, et. al, 2020; Sasmita, et. al., 2020). Recent cumulative data from the $64^{\text {th }}$ WHO situation report reveal that China (confirmed-81747, deaths-3283), South Korea (confirmed-9037, deaths-120) and Singapore (confirmed-507, deaths-2) may have successfully managed to suppress the spread of the virus with rapidly declining new confirmed cases and deaths while Europe (Italy: confirmed-62927, deaths-6077; Spain: confirmed-33089, deaths-2182; Germany: confirmed-29212, deaths-126; France: confirmed-19615, deaths-860; Switzerland: confirmed-8015, deaths-66 and United Kingdom: confirmed-6654, deaths-335) and the Americas (USA: confirmed-42162, deaths-471; Brazil: confirmed-1546, deaths-25; and Canada: confirmed-1432, deaths-20) have become the new COVID-19 hot spots probably due to high volume of travel and predominantly aging populations compounded by prevalent underlying conditions (WHO, 2020). The number of confirmed cases in Africa as at $25^{\text {th }}$ March 2020 are comparatively fewer with South Africa (confirmed-402, deaths-0) and Algeria (confirmed-231, deaths-17) reporting the highest number of cases. In Kenya, there are 28 confirmed cases, no deaths and over 500 people are suspected to have been exposed and are now on quarantine. It is very concerning that in the low and middle-income countries such Kenya the health protection systems tend to be weaker and laboratory resources may be meagre, infectious diseases notifications are often not timely and public health infrastructure is often weak. 
These ultimately render the disease surveillance systems in these countries ineffective. Without robust surveillance systems, health system would be blind are likely to be overwhelmed in cases of serious outbreaks like COVID-19 (Morse, 2007). Predictably, with time, the burden of infection may be heaviest in these countries.

Early patterns tend to reveal a trend similar to that SARS-CoV-1 and MERS-CoV where infection susceptibility can be associated with age, biological sex and other health conditions (Bogoch, et. al, 2020). Moreover, some workers are now postulating that the rapid spread of COVID-19 is likely driven by the phenomenon of "superspreading", the heightened transmission of the disease by a single person to at least eight contacts which has been observed for several infectious diseases including SARS, MERS and influenza (Shen, 2004; Lee, 2020). While the outcomes of the COVID-19 pandemic seem to be unpredictable, its story may have one of the following endings. The best-case scenario could be that spontaneously disappears as was the case with SARS in 2003. Or, it may continue to sporadically break out over many like MERS. If COVID-19 follows the path of the 1918 Spanish influenza pandemic, it may have a heavy toll in morbidity and mortality over decades to come with further ramifications in several sectors including health, agricultural, financial, sports, transport, tourism, manufacturing and education. Initial indications are unfriendly with very high transmissibility and fatality rate of up to $3.5 \%$ along with (Fisher \& Heymann, 2020).

\section{Study Findings}

One hundred and fourteen SMMEs from a different range of production units were included in this study, in addition to the five who participated in the pilot phase of the study. The study recorded $66.67 \%$ response rate which means that seventy-six (76) firms participated in the study. The non-response may have been occasioned by either or a combination of factors such as time constraint on the part of the interviewees, unwillingness and/or inability to respond to items on the questionnaire. The response rate from the various clusters is shown in Table 5.1.

Table 5.1: Response Rate

\begin{tabular}{|l|c|c|c|c|c|}
\hline \multirow{2}{*}{\multicolumn{1}{|c|}{ Stratum }} & \multicolumn{4}{|c|}{ Employment Levels } & \multirow{2}{*}{ TOTALS } \\
\cline { 2 - 5 } & $\mathbf{1 0 - 5 0}$ & $\mathbf{5 1 - 1 0 0}$ & $\mathbf{1 0 1}-\mathbf{1 5 0}$ & $\mathbf{1 5 1 - 2 0 0}$ & \\
\hline Food Processing & 5 & 4 & 5 & 3 & 17 \\
\hline Wood Workings & 4 & 5 & 2 & 2 & 13 \\
\hline Fabricated Metal Products & 6 & 3 & 5 & 2 & 16 \\
\hline Non-Metallic Products & 3 & 2 & 4 & 4 & 13 \\
\hline Leather, Textiles \& Garments & 3 & 5 & 4 & 5 & 17 \\
\hline \multicolumn{1}{|c|}{ TOTALS } & 21 & 19 & 20 & 16 & \multirow{2}{*}{$\mathbf{7 6}$} \\
\hline \multicolumn{1}{|c|}{$\%$} & $\mathbf{2 7 . 6}$ & $\mathbf{2 5}$ & $\mathbf{2 6 . 3}$ & $\mathbf{2 1 . 1}$ & \\
\hline
\end{tabular}

Table 5.1 shows that there was no significant difference in the sampled firm sizes since the responses were well distributed across the clusters in the target group. When asked to respond to issues related to possible supply chain disruption, the study established that $77.3 \%$ of the sampled firms have felt the impact of Coronavirus disease on their operations, with $63.7 \%$ of the sampled enterprises preparing to make adjustments such as renegotiating loan facilities with lenders and sending seasonal staff away until the situation improves. 54.5\% are operating below usual capacity, while $68.5 \%$ of the firms are planning to cut down on travel and corporate offsite events. $61.6 \%$ percent of the sampled firms reported having experienced disruption in their supply chain. $98.5 \%$ of the sampled firms are projecting stock out on inputs manufactured in United Kingdom, South Korea, Japan, India, Italy and especially China where Coronavirus disease was initially reported. With concern that international travel and social mass gatherings are helping spread the virus, $54.6 \%$ of the sampled firms are aware of the measures taken by the Kenya government such as invoking the Public Health Act, issuing advisories on hygiene, travel, social distancing, containment and embargos on airlines to cut back on cargo and passenger flights to many destinations around the world. 63.6\% have also found it difficult to ship in products due to lack of pre-shipment inspectors who are unavailable due to government lockdowns in source markets especially in China. Table 5.2 presents the mean responses on supply chain disruption items. 
Table 5.2: Items on SME Supply Chain Disruption

\begin{tabular}{lllllll}
\hline Opinion on item & $\begin{array}{l}\text { SD } \\
\text { \% }\end{array}$ & $\begin{array}{l}\text { D } \\
\text { \% }\end{array}$ & $\begin{array}{l}\text { NS } \\
\text { \% }\end{array}$ & $\begin{array}{l}\text { A } \\
\text { \% }\end{array}$ & $\begin{array}{l}\text { SA } \\
\text { \% }\end{array}$ & $\begin{array}{l}\text { Mean } \\
\text { response }\end{array}$ \\
\hline $\begin{array}{l}\text { The business has felt the impact of } \\
\begin{array}{l}\text { Coronavirus disease outbreak on its } \\
\text { operations }\end{array}\end{array}$ & - & 1.5 & 21.2 & 39.4 & 37.9 & 3.2 \\
\hline $\begin{array}{l}\text { The business is projecting stock out on } \\
\text { inputs manufactured out of the country }\end{array}$ & - & - & 1.5 & 69.7 & 28.8 & 4.3 \\
$\begin{array}{l}\text { The business is making adjustments in } \\
\text { response to Coronavirus disease outbreak }\end{array}$ & - & 7.6 & 28.8 & 56.1 & 7.6 & 2.4 \\
\hline $\begin{array}{l}\text { The business is operating below the usual } \\
\text { productivity levels and output }\end{array}$ & - & 3.0 & 42.4 & 54.5 & - & 3.4 \\
\hline $\begin{array}{l}\text { The business has cut down on travel and } \\
\text { corporate offsite events. }\end{array}$ & -3.0 & 28.5 & 68.5 & - & 2.7 \\
\hline $\begin{array}{l}\text { The business has found it difficult to ship } \\
\text { in products due to lack of pre-shipment } \\
\text { inspectors due to Coronavirus disease } \\
\text { outbreak }\end{array}$ & - & 12.1 & 24.2 & 63.6 & - & 2.1 \\
\hline $\begin{array}{l}\text { The business has experienced disruption } \\
\text { in the supply chain }\end{array}$ & - & & & & & \\
\hline $\begin{array}{l}\text { The business is aware of the measures } \\
\text { taken by the Kenya government in } \\
\text { response to Coronavirus disease outbreak }\end{array}$ & - & 1.5 & 43.9 & 45.5 & 9.1 & 2.6 \\
\hline
\end{tabular}

SD- Strongly disagree; D-Disagree; NS-Not sure; A-Agree; SA-Strongly agree

When asked what policies the Government can pursue so as to make the business environment more supportive to SMMEs considering the impact of coronavirus outbreak, six policy initiatives were identified by the respondents as presented in Table 5.3.

Table 5.3: Governmental Policy Initiatives

\begin{tabular}{lcc}
\hline Suggestions on Government Policy & f & \% \\
\hline & 31 & 40.7 \\
Tax holiday to allow the businesses to recover & 30 & 39.5 \\
Enhance local market access through buy Kenyan initiatives & 11 & 14.5 \\
Reform tax system to remove allow timely refunds & 10 & 13.2 \\
Fight against illicit trade & 8 & 10.5 \\
Security Improvement in the country & 5 & 6.6 \\
Enhance accountability by regulatory agencies & & \\
\end{tabular}

\section{Interpretation of the Findings}

The study results show that a large percentage of manufacturers in the SME sector in Kenya source their inputs or export to China and European countries. The impact of COVID-19 disease outbreak is therefore considerable and illustrates the importance that a severe novel disease can assume in a globalised and highly mobile world. Coronavirus disease outbreak has resulted in widespread social disruption as a result of some borders being closed and thousands of people placed in self or compulsory quarantine. These response strategies by many governments around the world have disrupted supply chains with many of the sampled small and medium manufacturing enterprises projecting stock out on inputs and inability to access local and international markets due to travel restrictions. The study findings imply difficulties for SME sector firms in their attempt to position themselves for competitiveness in a globalised business environment considering that SMEs are a heterogeneous set of businesses that face particular circumstances that impact on their operations. Difficulties for the SME sector firms has a wider economic and social implications in terms of potential job losses, poverty alleviation programmes, strain on health provision and reduced disposable incomes for majority of the populace in the lower income bracket. This has the potential to impact on Kenya's gross domestic 
product and the government's big four agenda touching on housing, health, job creation and food security. These findings therefore suggest that there is work to be done in policy reform to facilitate the SMEs in order to play their role in national development and towards the achievement of vision 2030 and the global sustainability agenda.

\section{Recommendations on Policy Initiatives}

Given the important role played by SMMEs in income generation and employment creation, the Kenyan government need to come up with specific legislative initiatives and policies geared towards facilitating them in the face of coronavirus disease outbreak and the consequent disruption in supply chains. This can be through short and long term policy initiatives directed at enhanced governmental response to new disease outbreaks, formation of industrial structures rich in linkages like clustering of SMMEs and subsequent subcontracting arrangements of these clusters with large enterprises, stimulus package for SMEs, import and export market diversification, enhanced local market access, reforming the tax systems to enable predictability and timely value added tax refunds, fight against illicit trade, embraced information technology to reduce government bureaucracy and enhance accountability by regulatory agencies.

\section{Conclusion}

The development of the SME Sector is regarded as critical towards overall economic and industrial take off in Kenya, yet Coronavirus disease pandemic continues to have a negative impact on SME sector firms with a cascading effect on Kenya's gross domestic product and the government's big four agenda. There is therefore need for the government of Kenya to formulate strategies that seek to speedily support SME sector firms, but also create a conducive environment that enables the SMEs in the long term compete in the global market.

\section{Acknowledgement}

We would like to acknowledge the support by the Kenyatta University management in availing a postmodern library for review of literature relevant to this study and facilitating the authors to attend learned conferences that were necessary in enriching this paper. To the research assistants who participated in data collection, the respondents and all those who contributed in one way or another in actualizing this study, we highly appreciate your contributions.

Declaration: We declare no competing interests and also take responsibility of any error(s) and/or omission(s) in the study findings, discussion, conclusions and recommendations contained in this study report.

\section{References}

Barney, J. (1991), Firm resources and sustained competitive advantage. Journal of Management, 17(1), 99-120.

Beck, T., Demirgüç-Kunt, A. and Levine, R. (2005).SME, Growth and Poverty." Cambridge, London, National Bureau of Economic Research.

Berman, J. (2020). Logistics Management, Modern Materials Handling, and Supply Chain Management Review

Bogoch, A. Watts, A. Thomas-Bachli, C. Huber, M.U.G. Kraemer \& K. Khan (2020). Pneumonia of unknown etiology in wuhan, China: potential for international spread via commercial air travel, J. Trav. Med. https://doi.org/10.1093/jtm/taaa008.

Casadevall, A. \& Pirofski, L (2020). The convalescent sera option for containing COVID-19. The Journal of Clinical Investigation, pp. 1-4. https://doi.org/10.1172/JCI138003.

Chan J.F, Yuan S, Kok KH (2020). A familial cluster of pneumonia associated with the 2019 novel coronavirus indicating person-to-person transmission: a study of a family cluster. [J]. Lancet, 2020, 395: 514-523.

Evans J. \& Lindsay W (2002). The Management and control of Quality $5^{\text {th }}$ Edition. South-Western Collage Publishing, Cincinnati, Ohio

Fisher, D., \& Heymann, D. (2020). Q\&A: The novel coronavirus outbreak causing COVID-19. BMC medicine, 18(1), 57. https://doi.org/10.1186/s12916-020-01533-w.

Flynn B.B. \& Flynn E. J. (2005). Synergies between supply chain management and quality management: Emerging Implications. International Journal of Production Research, (4) 31-36

Ghobadian, A, Gallear, D, (1996). 'Total Quality Management in SME's', Omega, International Journal of Management Science, Vol. 24 No. 1, pp 83-106

Helfat, C. \& Peteraf, M. (2003). The dynamic resource-based view: Capability lifecycles. Strategic Management Journal, 24(10): 997-1010.

Holcomb, R., Holmes, R. \& Conelly, B. (2009). Making the most of what you have: Managerial ability as a source of resources value creation. Strategic Management Journal, 30(5): 457-485 
Jara, J. \& Escaith, H., (2012). Global Value Chains, International Trade Statistics and Policymaking in a Flattening World, World Economics, 13(4):19-38

Kenya Manufacturers Association (2019).Survey of the Manufacturing Sector in Kenya.Kenya Association of Manufacturers, Nairobi.

KNBS (2019).Economic Survey, Kenya National Bureau of Statistics, Nairobi, Government Printers.

Kotler, P. (2007). "Marketing Management", New Delhi, Prentice Hall of India.

Krajewkil L. Ritzman L.P. \& Malhotra M.K. (2010). Operations Management: Processes \& Supply Chains. Pearson Education, Inc., Upper Saddle River, NJ.Kucharski, et. al, 2020

Krejcie, R.V. \& Morgan, D. W. (1970).Determining Sample Size for Research Activities. Educational and Psychological Measurement, 30, 607-610.

Lee, A. (2020). Wuhan novel coronavirus (COVID-19): why global control is challenging? Public Health Volume 179, February 2020, Pages A1-A2.

Levi D., Kaminksy P. \& Simchi-Levi E. (2008). Designing \& Managing the Supply Chain: Concepts, Strategies and Case Studies, Third Edition, McGraw-Hill, NY, NY

Levratto NL, Tessier M and Zouikri M (2010). The determinants of growth for SMEs. A longitudinal study of French manufacturing firms. Available at: http://ssrn.com/abstract1/1/4170466. DOI: 10.2139/ssrn.1780466.

Lu R, Zhao X, Li J (2020). Genomic characterization and epidemiology of 2019 novel coronavirus: implications for virus origins and receptor binding. [J]. Lancet, 2020 Jan 30

Lunati, M. (2007). Enhancing the Role of SMEs in Global Value Chains. SME and Entrepreneurship Division of the OECD Centre for Entrepreneurship, SMEs and Local Development (CFE). 68.

Malta, M., Rimoin, A. W., \& Strathdee, S. A. (2020). The coronavirus 2019-nCoV epidemic: Is hindsight 20/20?. EClinicalMedicine, 20, 100289. https://doi.org/10.1016/j.eclinm.2020.100289

Monezka R.M., Handfield R.B. Giunipero L.G \& Patterson J.L. (2009). Purchasing and Supply Chain Management $4^{\text {th }}$ Edition, South-Western Cengage Learning, Mason, OH.

Morse, S.S. (2007). Global Infectious Disease Surveillance and Health Intelligence.Health Affairs Vol. 26 . No.4 https://doi.org/10.1377/hlthaff.26.4.1069

Mwasiaji, E. (2020). Sustainability Reporting in the Context of Small and Medium Business Enterprises in Kenya: A Conceptual Framework: International Journal of Business Marketing and Management (IJBMM), 5(1), 13-22. ISSN: $2456-4559$.

Mwasiaji, E. (2019). The Effect of Government Policy on the Performance of Selected Manufacturing Enterprises in Kenya: International Journal of Economics, Business and Management Research, 3(12), 198-210. ISSN: 24567760

Nishiura H, Klinkenberg D, Roberts M, Heesterbeek JAP (2009). Early epidemiological assessment of the virulence of emerging infectious diseases: a case study of an influenza pandemic. PLoS One 2009; 4: e6852.

Nwankwo, S. \&Gbadamosi, A. (2010). Entrepreneurship Marketing: Principles and Practice of SME Marketing. Oxford, UK: Routledge.

Odhong E. A. and Were S. (2013). "Human Capital Management as a tool for value creation", in proceedings of First SHRD Annual Research Conference, 12th and 13th September 2013, Nairobi, Jomo Kenyatta University of Agriculture and Technology main campus.

Oslo Manual. (2005). Guidelines for collecting and interpreting innovation data. Organization for Economic Cooperation and Development (OECD). P. 166.

Penrose, E. (2003). The Theory of the growth of the firm. Oxford University Press, Cambridge. ISBN: 9780198289777

Republic of Kenya (2012). Kenya vision 2030: Ministry of State for Planning, National Development and Vision 2030. Sessional paper no. 10 of 2012. Nairobi: Government printer.

RoK, (2012).Micro and Small Enterprise Act of 2012.Nairobi, Government Printers.

RoK (2007). Kenya Vision 2030: A globally competitive and prosperous Kenya, Nairobi: Ministry of Planning and National Development and the National Economic and Social Council.

Rothe C, Schunk M, Sothmann P (2020). Transmission of 2019-nCoV Infection from an Asymptomatic Contact in Germany. [J]. N. Engl. J. Med., 2020, Jan 30

SasmitaPoudelAdhikari, Sha Meng, Yu-Ju Wu, Yu-Ping Mao, Rui-Xue Ye, Qing-Zhi Wang, Chang Sun, Sean Sylvia, Scott Rozelle, Hein Raat\&Huan Zhou (2020). Epidemiology, causes, clinical manifestation and diagnosis, prevention and control of coronavirus disease (COVID-19) during the early outbreak period: a scoping review. Infectious Diseases of Poverty, 9:29 https://doi.org/10.1186/s40249-020-00646-X

Scylla, R. (1982). Monetary Innovation in American. Journal of Economic History, 42(1):21-30.

Shen, Z., Ning, F., Zhou, W., He, X., Lin, C., Chin, D. P....Schuchat, A. (2004).Superspreading SARS Events, Beijing, 2003. Emerging Infectious Diseases, 10(2), 256-260.https://dx.doi.org/10.3201/eid1002.030732. 
Sinha, P., Akoorie, M.E.M, Ding \& Wu. (2011). What motivates manufacturing SMEs to outsource offshore in China?: Comparing the perspectives of SME manufacturers and their suppliers, Strategic Outsourcing: An International Journal , 4(1): 67-88.

Tuan, N. P. \& Yoshi, T. (2010). Vertical Linkage and Firm's Performance in Supporting industries in Vietnam. Asian Journal of Management Research, 1(1),1-14.

United Nations (2015).Transforming our world: The 2030 agenda for sustainable development. In Resolution Adopted by the General Assembly on 25 September 2015; RES/70/1; United Nations: New York, USA.

World Health Organization (2020).Coronavirus disease (COVID-2019) situation report 49 (10 Mar 2020). https://www.who.int/docs/default-source/coronaviruse/situation-reports/20200309-sitrep-49- covid-19.pdf (11 March, 2020, date accessed).

Ji. W., Wang, W., Zhao, X., Zai. \& Li, (2020). Cross- species transmission of the newly identified coronavirus 2019- nCoV. J.Med Virol, 92 (4): 433-440. https://doi.org/10.1002/jmv.25682

Wu J.T., Leung K., \& Leung G.M. (2020). Nowcasting and forecasting the potential domestic and international spread of the 2019-nCoV outbreak originating in Wuhan, China: a modelling study. Lancet.

Yeboah AM (2015) Determinants of SME growth: an empirical perspective of SMEs in the Cape Coast Metropolis, Ghana. The Journal of Business in Developing Nations 14(3): 1-21.Yusof\&Aspinwall, 2000;

Yu P, Zhu J, \& Zhang Z (2020). A familial cluster of infection associated with the 2019 novel coronavirus indicating potential person-to-person transmission during the incubation period. [J]. J. Infect. Dis., 2020 Feb 18.

Zhou P, Yang X, Wang X (2020). A pneumonia outbreak associated with a new coronavirus of probable bat origin. [J]. Nature, 2020, Feb 03, 2020. 